\title{
Creating an International Community during the Cold War
}

\section{Korsberg, Hanna}

Palgrave Macmillan

2017-06-19

Korsberg , H 2017 , Creating an International Community during the Cold War . in C Balme \& B Szymanski-Düll (eds), Theatre, Globalization and the Cold War . , 9 , Transnational Theatre Histories , Palgrave Macmillan , pp. 151-163 . https://doi.org/10.1007/978-3-319-48084-8_9

http://hdl.handle.net/10138/311651

https://doi.org/10.1007/978-3-319-48084-8_9

acceptedVersion

Downloaded from Helda, University of Helsinki institutional repository.

This is an electronic reprint of the original article.

This reprint may differ from the original in pagination and typographic detail.

Please cite the original version. 


\section{Hanna Korsberg}

Creating an International Community during the Cold War

\section{Abstract}

As the Cold War was fought on battlegrounds of rhetoric and impressions, culture had an important role to play in the process. The International Theatre Institute, ITI, founded in 1948, was a community with members from the two opposing camps of East and West. As a result, the Eighth Congress of the ITI in Helsinki in 1959 became a Cold-War battlefield. The keynote address about the avant-garde in contemporary theatre by Eugène Ionesco divided the audience. The division appears to have been a political one that followed the contours of the front line of the Cold War, since the strongest criticism came from the representatives of the Eastern Bloc. For a non-aligned country like Finland, balancing between East and West, the cooperation within the ITI was an important channel for internationalism.

After World War II, internationalism and nationalism were renegotiated in many countries. New international relationships were established and, for example, the United Nations was founded by 51 countries in 1945 . The purpose was to maintain international peace and security and develop friendly relations between nations. Later that same year 37 countries founded the United Nations Educational, Scientific and Cultural Organisation, UNESCO. The organisation aimed to establish the solidarity of mankind 'since wars begin in the minds of men, it is in the minds of men that the defences of peace must be constructed'. ${ }^{1}$ 
The founding of the International Theatre Institute (ITI), like the UN, was based on the different independent nations cooperating on an international level for mutual benefit. It was founded in the aftermath of World War II by 12 countries in Prague in 1948 and one of its objectives was to maintain peace: 'The concept has its basis in the conviction that the artists of the world speak a common language and can serve as valuable agents in obtaining mutual understanding and good will among nations. ${ }^{2}$ The ITI was an organisation that supported international cooperation in the field of performing arts. In particular, it seemed to be an organisation which non-aligned countries could also join. Despite these political and cultural attempts to create an international community, Europe especially was soon divided between two camps. In the early phases of the Cold War the division was mainly political, but also economic.

In this article I will discuss how theatre participated in the creation of an international community with members from both camps during the Cold War and, in particular, I will look closely at the Eighth Congress of the ITI that was organised in Helsinki in 1959. It was very important for the ITI to have members from both camps since, according to its charter, the organisation was autonomous. Unlike the previous congresses, in Helsinki there was a discussion about artistic questions in theatre. It was launched by a keynote address by playwright Eugène Ionesco. I will also discuss the attempts to define the theme of the Helsinki congress in 1959.

As the Cold War was a war fought on battlegrounds of rhetoric, impressions and discourse, culture and the arts played an important role in the battle for 'hearts and minds'. Speeches, newspaper articles and interviews about the ITI congress in 1959, together with Eugène Ionesco's keynote address, are examples of the rhetoric used to link theatre and internationalism. The concept of internationalism is much debated. In this case, the internationalism of theatre people across the world was based on mutual understanding and a need for the international exchange of practice and knowledge in theatre. Those cooperating 
within the framework of the ITI, especially in the 1950s, understood internationalism along the lines of the cosmopolitanism outlined by Kwame Anthony Appiah; that is, acknowledging a citizen who can see him/herself at home in more than one nation-state or community ${ }^{3}$.

Since both blocs fought to increase their influence, the Cold War battle was also conducted in the so-called non-aligned countries, and the international contacts were important for the non-aligned countries as well. To show how a non-aligned country, balancing between the two camps, was able to join the international cooperation, I would like to discuss the case of Finland. After World War II, Finland slowly returned to the international community. It was in a very sensitive geopolitical position between the two great powers. Right after the war, the preparations for the Peace Treaty inhibited any attempts by Finland to join the international community. For example, Finland had to refuse the Marshall Plan, the European rebuilding programme initiated by the USA in 1947. After the Paris Peace Treaty in 1947, the Foreign Ministry of Finland approached the General Secretary of the UN who set in motion Finland's application for membership. However, due to the Cold War and the fear of endangering the existing balance of power in the UN, Finland was not able to join the organisation until $1955 .{ }^{4}$ I argue that since Finland had to remain outside many especially political and economic - international alliances during the Cold War, culture and theatre in particular opened up new possibilities for international exchange. Though Finland was not one of the founding members of the ITI, it had sent two observers to the first meeting of the organisation in Prague in 1948. It also became an official member of the ITI in 1950. In fact, the ITI was one of the very first international organisations Finland could join in the post-war political climate.

The Eighth Congress of the ITI

During the period between 1948 and 1959, ITI congresses had been organised in Prague, 
Zurich, Paris, Oslo, The Hague, Dubrovnik and Athens. Some of the venues were in NATO countries, one of them a later Warsaw Pact state, one in the Cold War socialist economy of Yugoslavia and two in the militarily neutral Cold War capitalist societies of Switzerland and Finland. I would argue that in hosting congresses the ITI followed the first article of the charter of the organisation:

Since theatrical art is a universal expression of manking [mankind], and possesses the influence and power to link large groups of the world's peoples in the service of peace, an autonomous international organization has been formed, which bears the name of International Theatre Institute. The purpose of the Institute is to promote international exchange of knowledge and practice in theatre arts. ${ }^{5}$

The paragraph quoted from the charter connects the purpose of the ITI to the purpose of UNESCO. Art and theatre in particular were considered essential to create understanding between nations and thus were considered to play a vital role in the service of peace. The latter role was considered especially important during the years of the Cold War. Organising the congress of the ITI on both sides of the Iron Curtain was certainly an opportunity for geographical expansion and for the dissemination of information about the organisation.

The Eighth Congress of the ITI opened in Helsinki on 1 June 1959. The President of the ITI, Milan Bogdanović stressed the international importance of the organisation in his opening speech. According to him 'nothing in fact could exist in the field of international activities that could not prove its necessity and usefulness' ${ }^{6}$. He also argued that theatre was becoming an efficient international instrument and the existence of the ITI demonstrated that. According to Bogdanović:

It is almost possible to say that, in our days, a real International has appeared in the field of dramatic art. Theatre is essentially a functional art and its broad nature makes all limitations more and more difficult to support. National frontiers are already growing too narrow for it; international space is what it really needs. In fact, theatre 
uses a general language, the language which is the living appearance of man, his voice, his gestures, all the visible expressions which make the apprehension of all facts possible even for an audience unable to understand the words spoken on the stage. Theatre makes acquaintances and neighbours, friends and relatives of people of all colours. If, in our days, theatre could no more have an international activity, it would certainly decay and diminish. ${ }^{7}$

Bogdanović's speech can be discussed in terms of Benedict Anderson's concept of imagined communities. Anderson used the concept to discuss questions related to nationalism; he argued that the formation of nations and people's notions of belonging to a nation, for example, were shaped by novels, newspapers and languages. ${ }^{8}$ According to Bogdanović, theatre was using a general language and thus creating an international community. It was contending with forms of social and political discrimination and with racism, which was also declared as one objective of the ITI. ${ }^{9}$

In Helsinki, a total of 108 representatives from 33 countries gathered together; this represented a significant increase in the number of delegates. In Athens two years earlier, for example, there had been just 77 delegates from 28 countries. ${ }^{10}$ Among the delegates there were theatre directors, artists, critics and administrators. In contrast to the earlier congresses, this was the first congress at which artistic questions were discussed. Earlier, the focus had been only on administrative issues, like, for example, reducing the number of agents between theatre directors and playwrights and helping theatre groups to plan international tours. Naturally, these had been essential questions related to the internationalisation of theatrical art. In Helsinki, administrative issues were discussed, too, but they were accompanied by discussions about theatre as an art form. The subject of the debate was 'Avant-garde tendencies in the theatre of today'. The keynote address was given by the playwright Eugène Ionesco. He spoke about the avant-garde in contemporary theatre, the relationship between dramatic works and their audience, writing and his world view. 
I would like to argue that it is possible to draw an analogy between choosing the avant-garde as the subject of the discussions at the ITI congress and the use of a novel or newspaper to create a notion of belonging to the same community. Avant-garde plays were already read and performed and their authors were known in different countries by the theatre internationalists at the end of the 1950s.

Ionesco's avant-garde

In Ionesco's opinion, the main task of an author was to find the truth and express it in his writings. For Ionesco, the avant-garde was an artistic phenomenon and a forerunner of culture. According to him, the avant-garde could be defined in terms of opposition and rupture. The avant-garde was in an oppositional position towards the establishment. It was a reaction against realism, since realism was no longer capable of expressing the real world. The relationship between the avant-garde and the real world was thus governed by tension. According to Ionesco, the avant-garde was an expression of criticism of the present. It was also unpopular since it was characterised as demanding and difficult to understand. It was theatre for a minority and if it were to become theatre for the majority, it would no longer be avant-garde but instead arrière-garde. ${ }^{11}$

Ionesco also discussed ontological questions of art in his opening speech. According to him, artwork should be original and evoke an immediate intuition, an insight of truth. A talented artist would be able to provide both a deeper and wider intuition than a less-talented artist. In Ionesco's opinion, all the artist has to do is to provide an insight of truth. An authentic truth in theatre, an artwork, will have an effect on the audience. Realism and naturalism had helped to expand the concept of reality and reveal new aspects of it. Symbolism and surrealism had also expressed hidden facts. In his opinion, the avant-garde was a contemporary phenomenon which could be identified with artistic, literary theatre. ${ }^{12}$ 
For Ionesco, freedom was essential for the avant-garde. He placed it in opposition to propaganda theatre where the ideology was dominant. He also thought that playwrights were afraid of humour, even though humour represented one appearance of freedom. The only restrictions Ionesco could accept were the technical limitations of the stage. Otherwise the playwright should be completely free. The artist was not a pedagogue, nor a demagogue. More than anything, Ionesco stressed the freedom of the avant-garde theatre from all ideological restraints. ${ }^{13}$

Ionesco's keynote speech was followed by a heated debate. Most of the participants supported Ionesco, but some of them were very harsh in their criticism of him. The reactions seemed to follow a political division along the front line of the Cold War, since the strongest criticism came from the representatives of the Eastern Bloc: Romania (Aurel Baranga), Bulgaria (Bojan Danovsky), Czechoslovakia (Jaroslav Pokorny) and the USSR (A. Abalkin). The representative of the GDR, the intendant of the Deutsches Theater, Wolfgang Langhoff, also criticised Ionesco. According to them, Ionesco's plays did not represent the 'favourite readings of the peasants of Central Europe'. ${ }^{14}$ The representatives of the Eastern Bloc countries supported socialist realism and the definite truth concept. Ionesco was characterised as a 'chamber philosopher' whose ideas on ideologies were considered too personal and attached to his own world view. For similar reasons, the representatives of the Eastern Bloc were critical of Samuel Beckett as well. ${ }^{15}$

According to Aurel Baranga, a playwright and artistic director of the National Theatre in Bucharest, playwrights should not lead the audience into despair and loneliness as Eugène Ionesco and Samuel Beckett were doing in their plays. Instead they should adhere to the most important task of an author, which was teaching. Baranga believed that Ionesco had forgotten this in his writings. Besides, he thought that realism was not dead, but reshaped and alive. Baranga argued that there were other avant-garde authors who were proclaiming 'noble and courageous ideas', namely Federico Garcia Lorca, Bertolt Brecht and Vladimir Mayakovski. ${ }^{16}$ 
Bojan Danovsky accused Ionesco of denying life and making people miserable. In his reply, Ionesco argued that all representatives of the avant-garde belong to a minority, separate from the majority where his critics wanted to place all playwrights. According to Ionesco all important changes, including political events and ideologies, had started among small minorities. $^{17}$

One of the harshest critics was A. Albakin, the theatre critic of Pravda, who argued that Ionesco was a clown and could not be taken seriously. In his opinion, Ionesco's opening speech had turned the whole international congress into a circus. He did not have anything against the debate, but Ionesco was simply not competent enough to give the keynote address. ${ }^{18}$ Albakin's criticism seemed to be personal. It did not follow the state censors' opinion in the USSR, since, after Soviet Premier Khrushchev's denouncement of Stalinism in 1956, the state censors had allowed Ionesco's plays to be performed in theatres. ${ }^{19}$

However, Ionesco also received support from the participants. He was especially supported by the representatives of the UK (Harold Hobson), France (Jean-Jacques Bernard) and Belgium (van Vlanderen). ${ }^{20}$ The representatives of Finland also supported Ionesco. ${ }^{21}$ As hosts of the congress, the Finnish participants did not see any conflict of interest in supporting the author and encouraging the dispute.

The avant-garde was not new to the Finnish delegates. The very first play that can be categorised as avant-garde and later known as absurdist drama produced in Finland was Ionesco's The Lesson, which Vivica Bandler directed at the Kammarteatern at the beginning of 1953. She also directed the world premiere of The New Tenant at Lilla Teatern in 1955. Jack Witikka had directed two Samuel Beckett plays by 1959: Waiting for Godot in 1954 and Endgame in 1957, both at the Finnish National Theatre during Arvi Kivimaa's period as the general director of the theatre. Kivimaa was the chairperson of the organising committee of the ITI congress and an active agent in international cultural exchange. 
In my opinion, Witikka and Bandler were among the most internationally oriented theatre directors in Finland in the 1950s. They both had studied abroad, Bandler in France and Witikka in the UK. Actually, Vivica Bandler, who was also a friend of Ionesco, tried to pacify the debate by warning the congress representatives not to take themselves too seriously otherwise it would be easy to guess the topic of Ionesco's next play. ${ }^{22}$

Despite the three-day-long discussions about the definition of the avant-garde, the congress decided not to formulate any closing statements about the nature of the avant-garde. The secretary general of the ITI, Jean Darcante argued that the lively debate was the only closing statement the congress decided to give. ${ }^{23}$ It seemed to be the only conclusion all the delegates could accept since the opinions were extremely contradictory. It has been argued that the absurd seemed, according to Arnold Aronson, 'a logical, almost inevitable response to the irrationality of war' in Europe in the 1950s. ${ }^{24}$ The discussions at the Helsinki congress in 1959 do not support this claim unless Europe is understood as Western Europe, that is the countries that were aligned to the Western camp during the Cold War.

\section{Performing Politics between East and West}

The ITI congress was discussed a lot in the public sphere of modern politics. Altogether there were more than a hundred articles in different Finnish newspapers published all over the country. The articles described how a community of international theatre representatives from 33 countries had gathered together in Helsinki. The newspapers provided a lot of information about the ITI for their readers. Of particular interest is the large number of articles about Ionesco's keynote address and the subsequent discussion. It was the very first time the avantgarde had been extensively presented to the man on the street. Earlier, only individual productions had been reviewed in the newspapers.

Ionesco's keynote and the debate it caused were both summarised in the press. In 
particular, it was mentioned how Ionesco's presentation had divided the participants along the contours of the front line of the Cold War. Almost all the articles also mentioned that the Finnish participants had supported the Western camp. Politically the country could not be aligned and it had to balance between the two blocs; however, in the field of culture it was possible to lean towards the Western camp. The international theatre representatives wanted to show that Finnish theatre was comparable to European theatre. This had already been explicitly argued by Arvi Kivimaa some years earlier, in 1956. According to him, the national nature of Finnish culture had developed with the awareness of belonging to a larger European context. ${ }^{25}$ In my opinion, he was referring specifically to Western Europe, but in the political climate of 1956 this could not be argued overtly.

In 1959, the congress was also discussed in the public sphere of modern culture. Particularly, the Finnish Theatre Journal wrote very extensively about Ionesco's keynote address. ${ }^{26}$ The ITI congress increased the awareness of Ionesco's plays and the avant-garde in general among Finnish theatre artists and theatregoers. This seemed to be true especially right after the congress in summer 1959 and in the following season 1959-1960. A theatre called Taskuteatteri performed The Bald Soprano and The Lesson in Helsinki during the congress. During the following season Ionesco's The Chairs was performed at Intimiteatteri and Rhinoceros was staged at the Finnish National Theatre. The New Tenant returned to the repertory of the Lilla Teatern where it was seen together with The Lesson and a play by Boris Vian. $^{27}$

Before the ITI congress, the conception of art was dominated by an idea of popular nationalism: Finnish art was expected to present well-known topics in a realistic way. ${ }^{28}$ This had also affected the reception of avant-garde plays. In most of the reviews the critics had described the confused silence in the auditorium. Only a couple of professional critics knew the plays in advance and could compare the Finnish productions to the productions they had already seen abroad. For example, in her review of Rhinoceros, Sole Uexküll also discussed 
the reception the play had received in London, Paris and Gothenburg, though she saw Rhinoceros on stage for the first time at the Finnish National Theatre. ${ }^{29}$

Previously, all avant-garde plays had been performed at a couple of theatres in Helsinki, but in 1960 a theatre in the Jyväskylä municipality, Jyväskylän Huoneteatteri, also staged The Lesson. ${ }^{30}$ The ITI congress in 1959 brought about a considerable change in attitudes towards absurdist drama in Finland. It made a breakthrough and it was performed in small theatres and in established theatres as well. For example, at the end of the 1960s when Waiting for Godot returned to the repertory of the Finnish National Theatre it was already considered a modern drama classic. According to Arvi Kivimaa, in 1954 the play had been 'risky experimental drama'. ${ }^{31}$ He was referring to the artistic risk the theatre had taken by staging the play in 1954 when the avant-garde was relatively new to most theatergoers.

The political importance of the ITI congress

Besides the extensive writing in the newspapers, the importance of the congress can be seen from the use of public discourse. The opening ceremonies were attended by several highranking politicians, including the President of Finland, Urho Kekkonen, who was the patron of the congress, the Speaker of the House, K.-A. Fagerholm, the Prime Minister, V.J. Sukselainen, and the Minister of Education, Heikki Hosia. Minister Hosia also spoke at the opening ceremonies on behalf of the Finnish Government. He stated that theatre and the ITI connections were an important element in maintaining old and making new international contacts:

We have received great encouragement during the last years from the experience, gained in the main through the International Institute of Theatre, that our geographic position and our language do not form a separating wall between us and the principal countries in the field of dramatic art, but that there are, on the contrary, many 
possibilities for contacts and mutual understanding. The fact that the VIIIth

International Congress of Theatre is organized here is a new proof thereof. ${ }^{32}$

The political value of the ITI congress can also be seen in the fact that the state was the major financer of the congress, covering almost all the costs. The local organiser of the congress was the Central Association of Finnish Theatre Organizations, which was also the Finnish branch of the ITI. However, without the financial support from the state, the congress would not have been possible. Altogether, the Ministry of Education paid more than 91 per cent of the costs of the congress. The generous state support and the presence of the high-ranking politicians were typical for socialist policy. Thus Finland as a non-aligned country used the same strategies as countries in the Eastern Bloc to ensure international cooperation.

The ITI congress thus certainly changed the attitudes towards the theatre of the absurd in Finland. By hosting the ITI congress in 1959 and performing avant-garde drama, the theatre circles made a breakthrough and participated in the negotiations of Finland's position between East and West in 'No Man's Land', as Matti Kuusi described the country's geopolitical position. ${ }^{33}$ Finnish representatives of international theatre used the ITI congress and the performance of avant-garde plays to lean towards the Western camp. For the Finnish Government, the congress was a showcase for the success of Finland's international activities in attracting representatives of international theatre from different countries, and publicity for both camps. A similar event in the fields of politics or economics might not have been possible in Finland during the 1950s.

It has since been recognised that the ITI was an essential element in experimental theatre in relation to Off- and Off-Off-Broadway artists and productions. ${ }^{34}$ In my opinion, the ITI was also an important element earlier: in 1959 when Eugène Ionesco was invited as keynote speaker. Ionesco was a good representative of the second-wave modernism that had arisen in theatre and drama after World War II. At the time it was called avant-garde and only after Martin Esslin's The Theatre of the Absurd, which first appeared as an essay in 1960 and 
then as a book in 1961, was the term 'absurd' adopted. Despite the conflicting reactions, all the participants seemed to already know Ionesco's work. It was reported that this new element of the congress, the discussions concerning the avant-garde, attracted a lot of attention among representatives of international theatre all over the world. ${ }^{35}$

Regardless of the dispute in the discussions, four countries wanted to join the ITI. China and three countries from the Eastern Bloc (the GDR, Romania and the USSR) were also accepted as new members ${ }^{36}$. The new members thus increased the balance of power in the organisation. Since the ITI was operating in connection with UNESCO - officially from 1962 - it was important for the organisation to include countries from both blocs as its members. The ITI congress in Helsinki in 1959 was a moment of convergence between the participants and an important link in the mediation of cultural influence.

Abbreviations

ITI: International Theatre Institute

\footnotetext{
${ }^{1}$ The Constitution of UNESCO.

http://www.unesco.org/new/en/unesco/about-us/who-we-are/history/constitution/ date
} accessed 27 October 2014.

${ }^{2}$ Rosamond Gilder, "First Congress of the International Theatre Institute" Department of State Bulletin 19:485 (17 October 1948), 488-489.

${ }^{3}$ Kwame Anthony Appiah, Ethics of Identity (Princeton: Princeton University Press, 2005), 217.

${ }^{4}$ Jukka Nevakivi, "From the continuation war to the present, 1944-1999" in From Grand Duchy to a Modern State. A Political History of Finland since 1809, Osmo Jussila, Seppo Hentilä, Jukka Nevakivi (eds.) (London: Hurst \& Company, 1999), 217-356, 282-4. 
The Eighth Congress of the ITI

${ }^{5}$ ITI "The Charter of the ITI", The programme of the Eighth Congress of the ITI 1.-7.VI

Helsinki, The Collection of Albert Saloranta, The Finnish Theatre Museum Archives, ITI VIII kongressi H:ki 1959.

${ }^{6}$ ITI The programme of the Eighth Congress of the ITI 1.-7.VI Helsinki, The Collection of Albert Saloranta, The Finnish Theatre Museum Archives, ITI VIII kongressi H:ki 1959.

${ }^{7}$ ITI The programme of the Eighth Congress of the ITI 1.-7.VI Helsinki, The Collection of Albert Saloranta, The Finnish Theatre Museum Archives, ITI VIII kongressi H:ki 1959.

${ }^{8}$ Benedict Anderson, Imagined Communities. Reflections on the Origin and Spread of Nationalism (London and New York: Verso, 1991), 25 and 77.

${ }^{9}$ The objectives of the ITI can be found, for example, on the organization's webpage (see ITI, 2012).

${ }^{10}$ Central Association of the Finnish Theatre Organizations 'Report of the Eighth Congress of the ITI from the Central Association of the Finnish Theatre Organizations to the Ministry of Education', 11 September, Archives of the Ministry of Education, The National Archives of Finland, AD 1485/291.

Ionesco's avant-garde

${ }^{11}$ Eugène Ionesco, “Avant garde on nykyhetken kritiikki I-III” Teatteri 12, 13, 15, 1959.

${ }^{12}$ Aamulehti, "Ei suuren yleisön teatteria eikä saisi siksi tullakaan”, 4 June 1959, and Eugène Ionesco, “Avant garde on nykyhetken kritiikki I-III” Teatteri 12, 13, 15, 1959.

${ }^{13}$ Aamulehti, "Ei suuren yleisön teatteria eikä saisi siksi tullakaan”, 4 June 1959, and Eugène Ionesco, “Avant garde on nykyhetken kritiikki I-III” Teatteri 12, 13, 15.1959.

${ }^{14}$ Aamulehti, “Avantgardismi kiivaitten hyökkäysten ristitulessa”, 5 June 1959.

${ }^{15}$ Aamulehti, "Avantgardismi kiivaitten hyökkäysten ristitulessa", 5 June 1959.

${ }^{16}$ Kansan Uutiset, “Avantgardismia kymmenissä erilaisissa muodoissa”, 5 June 1959. 
${ }^{17}$ Suomen Sosialidemokraatti, "Avantgardismista keskusteltiin Realistit vastustavana puolena", 6 June 1959.

${ }^{18}$ Helsingin Sanomat, "Pravdan kriitikko teilaa Ionescon ja kiittää "Reviisoria", 7 June 1959.

${ }^{19}$ Philip B. Zarrilli, Bruce McConachie, Gary Jay Williams and Carol Fisher Sorgenfrei, Theatre Histories: An Introduction (New York and London: Routledge, 2006), 345.

${ }^{20}$ Helsingin Sanomat, "ITI:n kongressin jälkikaikuja”, 12 June 1959.

${ }^{21}$ Helsingin Sanomat, "Teatterin nuoria tuettava mielipide-eroista huolimatta", 5 June 1959.

${ }^{22}$ Helsingin Sanomat, "Teatterin nuoria tuettava mielipide-eroista huolimatta", 5 June 1959.

${ }^{23}$ Uusi Suomi, "ITI hyväksyi uusia jäseniä”, 5 June 1959.

${ }^{24}$ Arnold Aronson, "American Theatre in Context" The Cambridge History of American

Theatre. Volume III Post-World War II to the 1990s, eds D. B. Wilmeth and C. Bigsby

(Cambridge: Cambridge University Press, 2000), 87-162, 113.

Performing Politics between East and West

${ }^{25}$ Arvi Kivimaa, Teatterin humanismi (Keuruu: Otava, 1972), 71.

${ }^{26}$ For example, Teatteri 12, 13 and 15/1959. The term 'public sphere' (German Öffentlichkeit) (intermediary and cultural) originates from Jürgen Habermas. Erkki Sevänen has applied it to Finnish society. Sevänen quotes Jürgen Habermas, according to whom state and civil society were differentiated with the modernisation of society. This differentiation was not complete and the public sphere remained as an intermediary between the state and civil society. The main representatives of this intermediary public sphere include the parliamentary system and the media. They are also at the centre of the public sphere of modern politics. The public sphere of modern culture, for its part, has been represented by such things as theatre performances, literary publishing, and the cultural press. Erkki Sevänen, ”Ensimmäisen tasavallan poliittinen tilanne ja kirjallisen älymystön toimintastrategiat”. In Älymystön jäljillä. Kirjoituksia suomalaisesta sivistyneistöstä ja älymystöstä, Pentti Karkama, Hanne Koivisto (eds.) (Helsinki: Suomalaisen Kirjallisuuden Seura, 1997), 33-63, 37 and 49. 
${ }^{27}$ Lilla Teatern advertised its repertory for the fall of 1960 under the title 'The Modern Line'. Ionesco was going to be performed in a revue (Lilla Teatern, 1960).

${ }^{28}$ Erkki Sevänen, Taide instituutiona ja järjestelmänä. Modernin taide-elämän historiallissosiologiset mallit (Helsinki: Suomalaisen Kirjallisuuden Seura, 1998), 341.

${ }^{29}$ Sole Uexküll, "Sarvikuonot valloillaan”, Helsingin Sanomat, 18 October 1960.

${ }^{30}$ Ilona, ILONA a Finnish theatre database of performances, http://ilona.tinfo.fi/ (home page), date accessed 26 September 2014.

${ }^{31}$ Aryi Kivimaa, Teatterin humanismi (Keuruu: Otava, 1972), 193.

The political importance of the ITI congress

${ }^{32}$ Heikki Hosia, "Minister of Education Heikki Hosia's speech at the Opening Ceremonies of the Eighth Congress of the ITI", 1959, The Collection of Albert Saloranta, The Finnish Theatre Museum Archives.

${ }^{33}$ Eino S.Repo (ed.), Toiset pidot Tornissa ( Jyväskylä: Gummerus, 1954), 13-16.

${ }^{34}$ Mel Gussow "Off- and Off-Off Broadway" in The Cambridge History of American

Theatre. Volume III Post-World War II to the 1990s eds D. B. Wilmeth and C. Bigsby

(Cambridge: Cambridge University Press, 2000), 196-223, 220.

${ }^{35}$ ITI, The ITI's report on its activities in 1958 and 1959 to UNESCO, 1959,

http://unesdoc.unesco.org/images/0014/001429/142938eb.pdf, date accessed 29 October 2014.

${ }^{36}$ Uusi Suomi, “ITI hyväksyi uusia jäseniä”, 5 June 1959.

Since 2008, Hanna Korsberg has been appointed as Professor of Theatre Research at the University of Helsinki. Her research interests include the relationship between theatre and politics in Finland, a topic which she has studied in two monographies. She is also the author of several articles discussing theatre history, historiography and performance analysis. She has been an active member of the IFTR Historiography Working Group since 2001, an executive committee member in 2007-2015 and a vice president 2015-2019. She has served 
as a member of the advisory boards in Contemporary Theatre Review and Nordic Theatre Studies. Also, she is a member of the Teachers' Academy at the University of Helsinki. 